\title{
Güncel Tasarım Yaklaşımlarına Genel Bir Bakış
}

\section{An Overview on Current Design Approaches}

\section{Tevfik İnanç İlisulu}

Doç., Ankara Hacı Bayram Veli Üniversitesi Güzel Sanatlar Fakültesi Görsel İletişim Tasarımı Bölümü email: inancilisulu@gmail.com (DORCID ID: https://orcid.org/0000-0002-7387-4492

Atıf (APA 6)/To cite this article

İlisulu, T. İ. (2019). Güncel tasarım yaklaşımlarına genel bir bakış. Atatürk Üniversitesi Güzel Sanatlar Enstitüsü Dergisi, 43, 20-36. doi: https://doi.org/10.35247/ataunigsed.536788

Makale Gönderim Tarihi/Received: 07/03/2019

Makale Kabul Tarihi/Accepted: 29/09/2019

Makale Yayın Tarihi/Published/: 26/10/2019

Review Article/Derleme Makalesi

$\ddot{O} z$

Tipografiden illüstrasyona, hareketli grafiklerden renk kullanımına kadar grafik tasarımın tüm bileșenleri sürekli olarak gelişimlerini/değişimlerini gerçekleştirerek zamanı yakalamak zorundadır. Grafik tasarım alanında hem akademisyenlerin hem de profesyonel tasarımciların yıl içerisinde oluşan tasarım eğilimlerini analiz ederek incelemeleri, bir sonraki yıl/yıllarda hangi tasarım yaklaşımlarının oluşabileceği konusunda kendilerinin fikir sahibi olmalarını sağlayacaktır. Çalışmanın amacı güncel grafik tasarım yaklaşımlarının nelerden ve nasıl etkilendiğinin anlaşılabilmesidir. Bu nedenle, makale içerisinde güncel tasarım yaklaşımları; Parlak, Canlı ve Geçişli Renk Kullanımları, Üç Boyutlu İllüstrasyon Uygulamaları, Dijital ve Üç Boyutlu Tipografi Tasarımları, İzometrik (Eşölçülü) Tasarımlar, Sanal Gerçeklik (Virtual Reality) olmak üzere bes farklı başlık altında nitel araștırma yöntemleri kullanılarak incelenmiştir. Bu açıdan makalenin önümüzdeki yıllar için grafik tasarımcıların "tasarım eğilimleri" hakkında fikir sahibi olmalarına katkıda bulunacağı düşünülmektedir.

Anahtar kelimeler: Tasarım Yaklaşımları, Grafik Tasarım, Görsel İletișim

\begin{abstract}
From typography to illustration, from motion graphics to the use of colour, all components of graphic design must capture time. In the field of graphic design, both academicians and professional designers have to analyse the design trends that appear during the year. This will enable them to have an idea of what design approaches can appear in the following years. For this reason, current design approaches are examined under five different headings: Bright and Vivid Colour Uses, Three Dimensional Illustrations, Digital and Three Dimensional Typography Designs, Isometric Designs, Virtual Reality. In this way, it is thought that graphic designers will have an idea about "design approaches" for the coming years.
\end{abstract}

Keywords: Design Approaches, Graphic Design, Visual Communication

\section{Giriş}

Günümüzde iletişimin temelini oluşturan tüm alanlarda çok hızlı bir değişim olduğu görülmektedir. Bunun çeşitli sebepleri olmakla birlikte teknolojinin etkisi çok büyüktür. Gelişen teknolojinin sunduğu olanaklar sayesinde hem iletişim alanları çeşitlenmekte hem de iletişim biçimleri değişmektedir. Bu durum grafik tasarım alanını da geri dönülmez biçimde temelden etkilemiştir. Grafik tasarımcıların, sürekli değişen tasarım yaklaşımlarının sabit olan tek gerçek olduğunun bilincinde ve yarın gelecek olana hazırlıklı olmaları gerekmektedir.

Doksanlı yıllara kadar çoğunlukla basılı medya ile birlikte görsel medya olarak yalnızca televizyon iletişim aracı olarak kullanılmaktaydı. Günümüzde ise kol saatimizden telefonumuza, tablet bilgisayarımızdan araba ekranlarımıza kadar bu çeşitlilik artmış ve artmaya devam etmektedir. Bu hızlı değişimin devam etmesi her geçen gün yeni tasarım yaklaşımlarını da beraberinde getirmektedir. Bununla birlikte birkaç yıl öncesine kadar modern yaklaşımlar olarak gördüğümüz çoğu tasarımın 2019 yılında görsel etkisini kaybettiğini, bir başka ifadeyle modasının geçtiğini görmekteyiz. Bazı tasarım eğilimleri zaman karşısında zorlu sınavlar verirken birçok tasarım eğilimi de göz açıp kapayıncaya kadar kaybolup gitmektedir. Bu değişimleri yakından takip etmek ve yeni yaklaşımları ön görmek artık tasarımcıların yeni görevlerinden birdir denebilir. Bu görevin yapılmaması çağı yakalayamamak ve tasarım açısından geride kalmak anlamlarını taşımaktadır. Bu açıdan günümüz tasarım yaklaşımlarını, Parlak, Canlı ve Geçişli Renk Kullanımları, Üç Boyutlu İllüstrasyon Uygulamaları, Dijital ve Üç Boyutlu Tipografi Tasarımları, İzometrik (Eşölçülü) Tasarımlar, Sanal Gerçeklik (Virtual Reality) olmak üzere beş ayrı başlık altında incelemek yerinde olacaktır.

\section{Yöntem}

Nitel araştırma yönteminin kullanıldığı çalışmanın deseni “durum çalışması”, türü ise "açıklayıcı durum çalışması"dır. Ayrıca nitel veri toplama araçlarından "doküman incelemesi” tekniği de kullanılarak grafik tasarım alanında üretilen çalışmalar farklı başlıklar altında araştırılarak güncel tasarım yaklaşımları ortaya konmuştur. 


\section{Parlak, canlı ve geçişli renk kullanımları}

Renk, grafik tasarım alanının en önemli ögelerinden biridir. Tasarım içerisinde doğru biçimde kullanıldığında, bir duyguyu ifade edebildiği gibi dikkat çekici ve farklılaştırıcı olabilmektedir. Bir tasarımda renk, birçok amaca hizmet eder. Tasarım ya da resme uzamsal bir nitelik, ton farklılıklarını sağlayarak da plastik değer kazandırır; arka ve ön plan etkileşimiyle ilgi yaratır, kişisel duygu ve düşüncelerimizi dışa vurur; kompozisyon içerisinde birliğin sağlanması amacıyla dikkat çekmek ve yönlendirmek için kullanılır (Öztuna, 2007, s. 90). Teknolojinin hızlı gelişimi ile birlikte son yıllarda tasarım içerisinde renk uygulamaları önemli ölçüde değişmiş, özellikle parlak, canlı ve kontrast renk kullanımı ön plana çıkmıştır. Grafik Tasarımcılar Meslek Kuruluşu (GMK) tarafından 19 Ocak 2019 tarihinde düzenlenen etkinlik afiși bu kullanıma iyi bir örnek olarak gösterilebilir (Görsel 1). 2019 Ocak ayında İspanya'da kötü alışkanlıklara karşı hazırlanan sosyal kampanyanın tanıtım afişinde yine kontrast ve parlak renklerin kullanımı dikkat çekmektedir (Görsel 2).

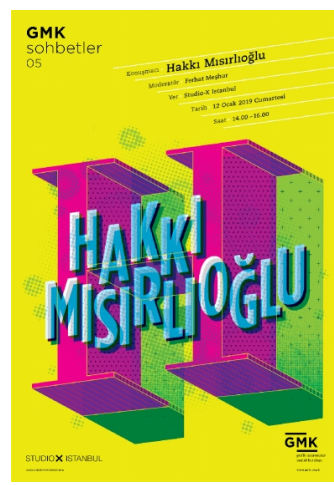

Görsel 1. Hakkı Mısırlığlu, etkinlik afiş tasarımı, 2019

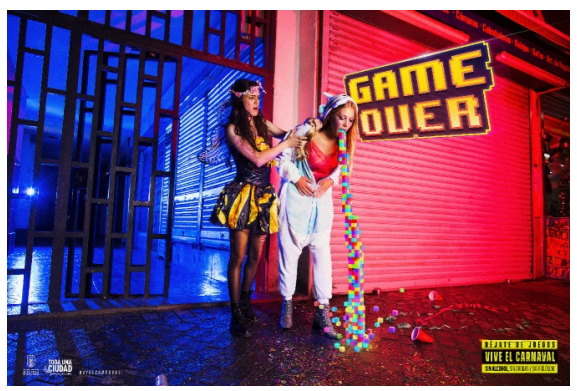

Görsel 2. Game Over, sosyal kampanya afiş tasarımı, 2019

Renk söz konusu olduğunda özellikle tasarım alanında öne çıkan bir kavramdan söz etmek gerekmektedir; Kullanıcı Arayüzü (User Interface ). Çoğunlukla dijital alanlar için kullanılan bu terim, arayüz tasarımını ifade etmekte, internet siteleri, telefonlar, televizyonlar, araç içi görüntü sistemleri ve bunun gibi kullanıcı arayüzü gerektiren tüm ortamlarda karşımıza çıkmaktadır. İçeriğini, renkler, butonlar, boşluk-doluluk ilişkileri, ızgara (grid) yapıları gibi grafik ögeler oluşturmaktadır. İletişim ortamlarının vazgeçilmez biçimde kullanıcıyla etkileşime girmeye başlamasıyla birlikte önemi artmıştır. Arayüzler, özellikle etkileyici renk seçimleri sayesinde kullanıcıyı uyarmakta, yönlendirmekte, geçişli (grade) renk tonları ve canlı renklerin kullanılmasıyla birlikte görsel etkinin arttırılarak, farkındalık yaratılmasını sağlamaktadırlar. Iphone telefon kullanıcı örneğinde açılış arayüzünün canlı, parlak ve geçişli renk tonlarında olduğu, iç arayüzlerin ise bu canlı arka plan üzerinde kontrast yaratacak biçimde daha düz -geçişli olmayan- renkler kullanılarak tasarlandığı görülmektedir (Görsel 3).
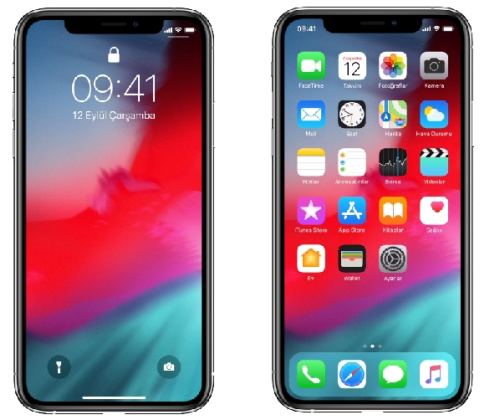

Görsel 3. IPhone X arayüzü, 2019 
Bununla birlikte minimal tasarım yaklaşımı içerisinde Görsel 4 ve Görsel 5'de görüldüğü gibi siyah veya beyaz zemin kullanımları geçtiğimiz yıllarla birlikte bu yıl da kullanılmaya devam etse de 2018 yılı içerisinde özellikle parlak renk kullanımları etkileyici bir biçimde artmıştır. Görsel 6 ve Görsel 7 örneklerinde olduğu gibi koyu mor (ultra violet) renk tonları bu yılın en çok tercih edilen kullanımlarından birisidir. 2018 yılının rengi seçilen ve ultra violet 18-3838 adıyla Pantone kataloğunda yer alan bu renk teknoloji, gelecek ve uzayla özdeşleştirilirken, gezegenler ve yıldızları işaret ederek keşfetme ve merak duygularını da işaret etmektedir (Görsel 8). Rengin "Yaratıcı ve hayal gücü kuvvetli olan Ultra Violet, henüz ulaşılmamış olana giden yolu aydınlatıyor." olarak tanımlanması da bunun bir göstergesidir (Pantone, 2018).

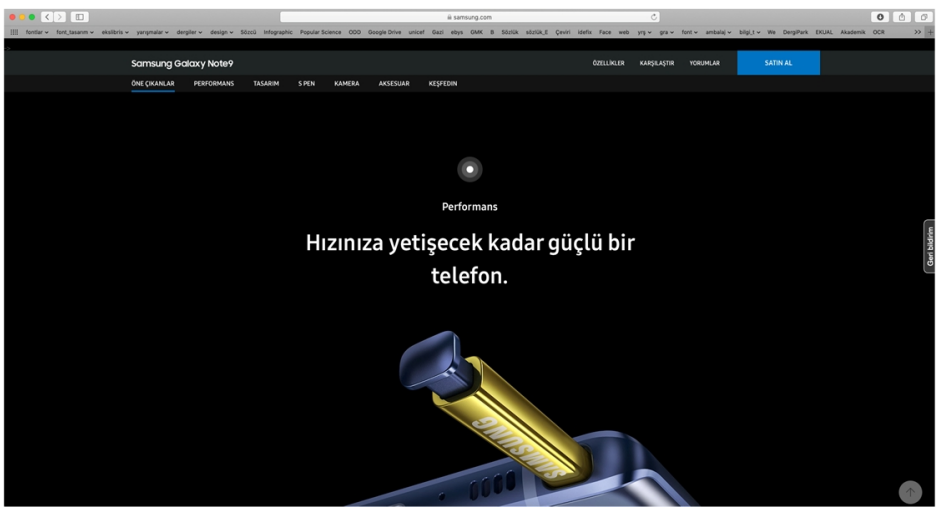

Görsel 4. Samsung Galaxy Note 9 web sayfası tasarımı, 2019

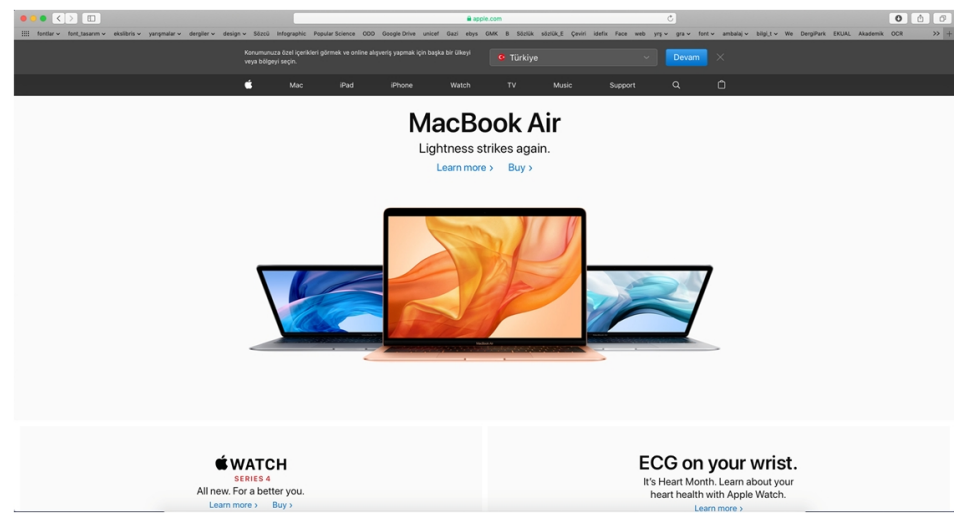

Görsel 5. Apple MacBook Air web sayfası tasarımı, 2019

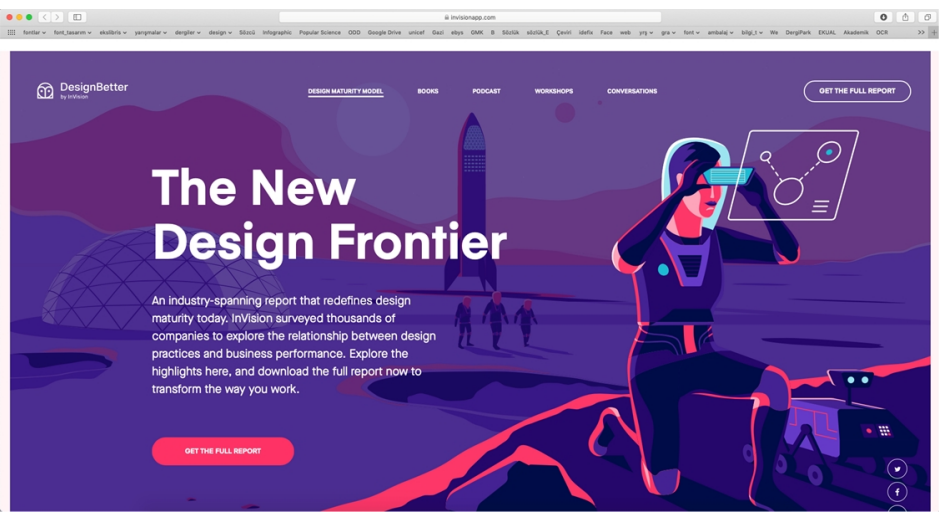

Görsel 6. Design Better web sayfası tasarımı, 2019 


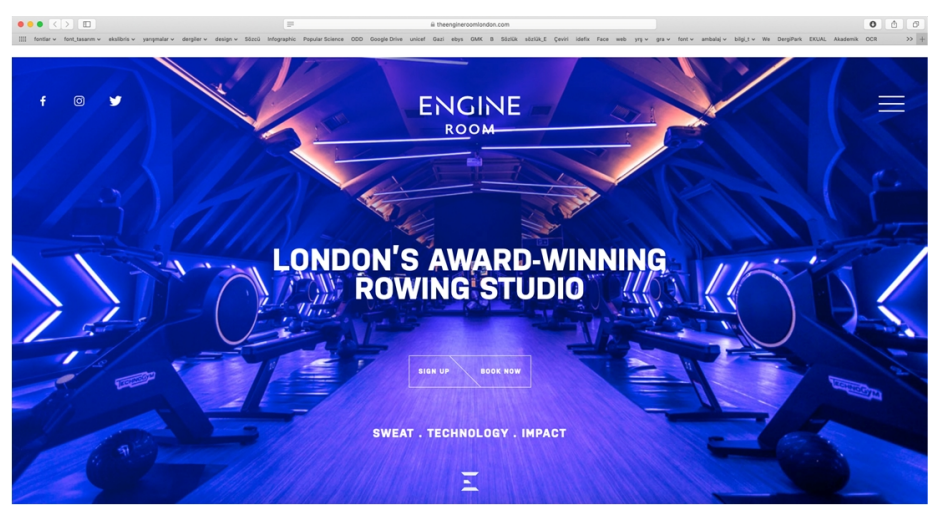

Görsel 7. The Engine Room London web sayfası tasarımı, 2019

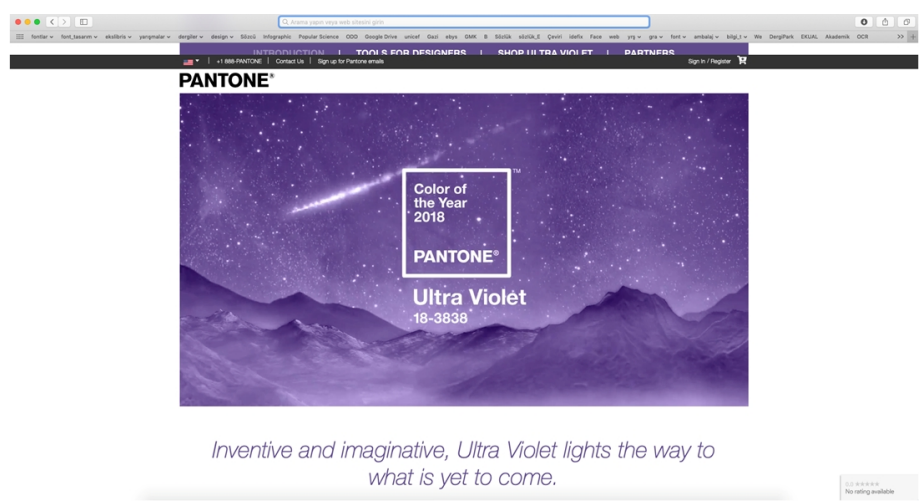

Görsel 8. Pantone kataloğu web sayfas1, yılın rengi: ultra violet 18-3838, 2018

Teknolojinin etkileri her alanda kendini gösterirken, otomotiv sektörünün de bu değişimden payına düşeni aldığını söyleyebiliriz. Özellikle iç mekân tasarımlarının hızla değiştiği, daha etkin ve fonksiyonel gösterge panellerinin bir ihtiyaca dönüştüğü, bu nedenle kökten bir değişiklik içine girildiği görülmektedir. Manual gösterge panellerinin yerini dijital olanlara bıraktığı 2018 yılında artık grafik tasarımcılar için yepyeni uygulama alanları ortaya çıkmıştır. 2018 yılında bir otomobil markası yeni aracında gösterge paneli ile birlikte araç kontrol ve ses sisteminin tamamını dijital tek bir ekrandan oluşacak biçimde tasarlamıştır. Sürücüye daha etkin bir kullanım deneyimi sağlamak için kullanıcı arayüz tasarımlarında mavi/mor, parlak ve geçişli renk tonlarının kullanımı tercih edilmiştir (Görsel 9). Grafik tasarım alanı içerisinde daha önceleri fazlaca tercih edilmese de özellikle web siteleri ve diğer dijital tasarım uygulamalarında bu ve bunun gibi canlı/parlak renklerin önümüzde ki y1l/yıllarda da kullanılma potansiyeli olduğu söylenebilir.

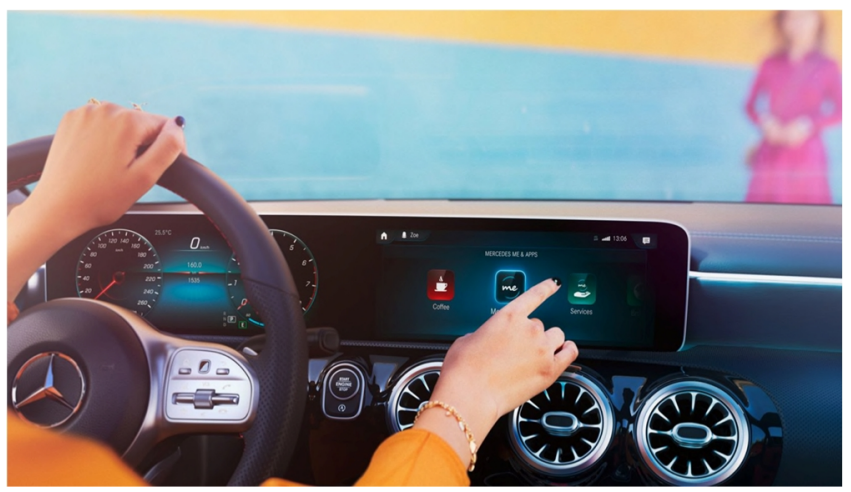

Görsel 9. Mercedes A Serisi iç mekân gösterge paneli, 2019

\section{4. Üç boyutlu illüstrasyon uygulamaları}

Yakın zamana kadar çizimler kâğıt üzerinde yapılıp sonrasında taranarak bilgisayar ortamına aktarılmaktaydı. Ancak günümüze gelindiğinde çağdaş illüstrasyon, hem geleneksel hem de dijital olarak bilgisayar ortamlarının kullanılmasını içermektedir (Male, 2017, s. 11). Son yıllarda özellikle hareketli ve durağan üç boyutlu tasarım uygulamalarının hızla arttığını görmekteyiz. Çizim tabletleri ve dokunmatik çizim ekranları teknolojisi ile birlikte 
uygulamalar çeşitlilik kazanmış, bu yeni araçlar sanatçılar ve tasarımcıların el çizimlerini dijitalle birleştirmesini çok kolay ve uygulanabilir hale getirmiştir. Özellikle üç boyutlu illüstrasyon tasarımlarında geleneksel ve dijitalin birleştirilerek kullanılması, ortaya çıkan ürünlerin kişiselleşmesini ve benzersiz olmasını da sağlamıştır. Grafik tasarım alanında hazır görsellere (stok imaj) ulaşmanın çok kolay olması ve bu yönteme sıklıkla başvurulması ortaya çıkan ürünlerin birbirine benzemesine neden olmaktadır. Böylesi bir ortamda yukarıda sözü geçen teknolojiler tasarımcının farkındalık yaratabilmesine de olanak sağlamaktadır (Görsel 10).

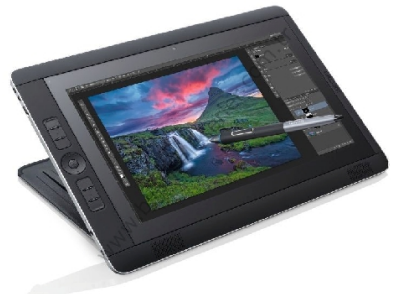

Görsel 10. Wacom çizim tableti, 2019

2004 yılında Absolut içecek firması için TBWA reklam ajansı bir reklam kampanyası hazırlamıştır. Yayınlanan reklamlarda kullanılan illüstrasyonların zamanı için oldukça başarılı olduğu söylenebilir. Steven Heller bu kampanya için “Akıllıca uygulanan grafik tasarım ve güçlü tipografi uygulaması” ifadelerini kullanmıştır (Heller, 2009, s. 28). Ancak reklamlarda kullanılan iletişim biçimi aynı olsa da, yine aynı ajans tarafından 2008 ve 2013 yıllarında yapılan diğer kampanyalarda, renk kullanımı, tasarım biçimi ve illüstrasyonların büyük ölçüde değiştiği görülmektedir. Tasarımda kullanılan teknolojilerin gelişmesi illüstrasyonlara çeşitli şekillerde yansımakta, bu sayede farkındalık, etkileyicilik ve gerçekçilik aynı oranda artmaktadır (Görsel 11, Görsel 12, Görsel 13).

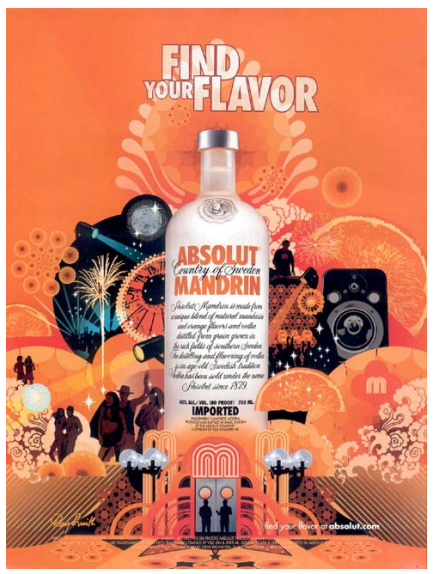

Görsel 11. Absolut içecek firması afiş tasarımı, 2004

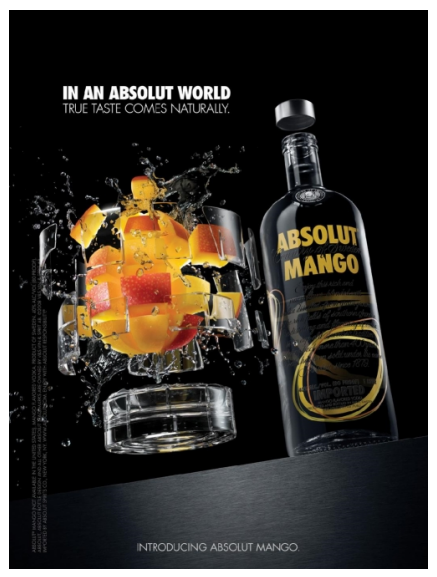

Görsel 12. Absolut içecek firması afiş tasarımı, 2008 


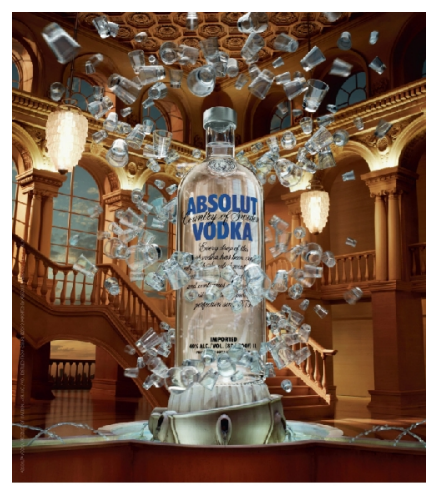

ABSOLUT CATALYST

Görsel 13. Absolut içecek firması afiş tasarımı, 2013

Görsel 14 ve Görsel 15'de ise artık üç boyutlu gerçekçi (reel) illüstrasyonların etkili biçimde kullanıldığı ve bu kullanım biçiminin önümüzdeki yıllarda grafik tasarımcıları tarafından tercih edileceği söylenebilir.

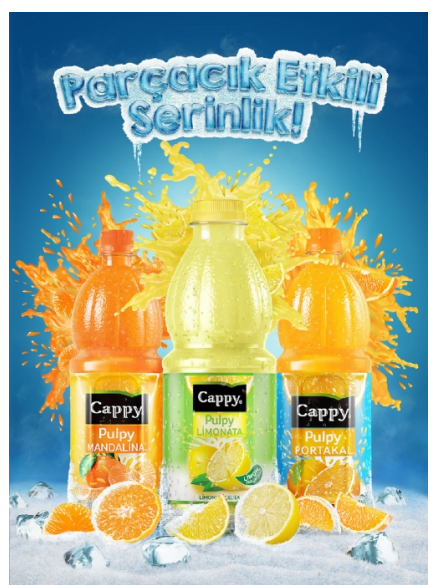

Görsel 14. Cappy Pulpy Mandalina afiş tasarımı

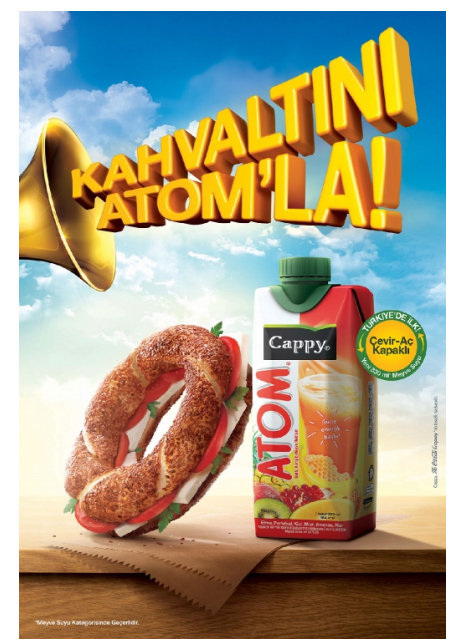

Görsel 15. Cappy Atom afiş tasarımı

Grafik tasarım ve görsel iletişim alanlarında, gerçekçi üç boyutlu illüstrasyonların yanında yine üç boyutlu illüstrasyon olarak tanımlayabileceğimiz ancak gerçekçi görüntü vermeyen çalışmalara da son yıllarda sıklıkla rastlanmaktadır. Bu illüstrasyonlar hazırlanırken yine gelişen teknolojiler tasarımcılara birçok imkân sunmaktadır. Bununla beraber tasarımların izleyiciye verdiği duygu gerçeklikten farklı olarak üç boyut hissidir. Bu hissi tasarımcılar doku, form, renk ve gölgelendirmeler yaparak vermeye çalışmaktadırlar. Cinema 4D, Maya, 3Dmax gibi vektörel bazlı programlar kullanılarak hazırlanan bu illüstrasyonlar tasarımcının bir anlamda daha etkin 
çalışmalarına olanak sağlamaktadırlar. Işık bu programlarda en önemli ögedir ve doğru kullanıldığında gölge, renk doku gibi formların da yardımıyla istenilen üç boyut etkisi verilebilmektedir (Görsel 16).

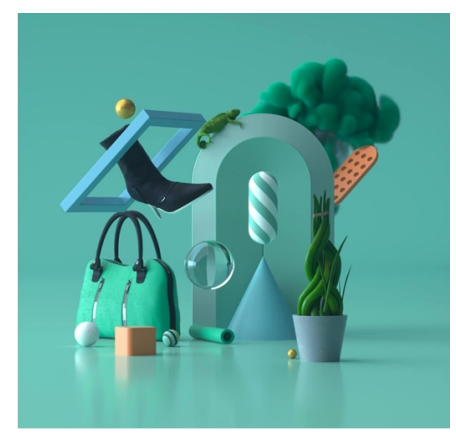

Görsel 16. Cinema 4D Programıyla hazırlanan tasarım örneği, 2019

Audi otomobil firmasının 2013 Aralık ayında yayınladığı reklamında, dört çeker aracının her mevsimde yol tutuşunu anlatan üç boyutlu bir illüstrasyon çalışması görülmektedir. Burada amaç, gerçekçi bir yaklaşım yerine tasarımda üç boyut duygusu ile izleyicinin ilgisini çekerek mesajı iletmektir (Görsel 17).

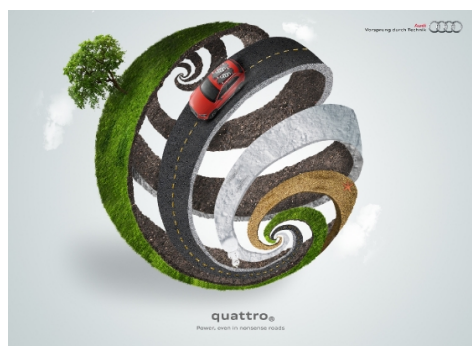

Görsel 17. Audi Quattro afiş tasarımı, 2013

Mart 2017 yılında Rusya'da yayınlanan bir inşaat firması reklamında da yine üç boyutlu illüstrasyon çalışması kullanılmıştır. Mesaj, etkileyici renklerinde yardımıyla dikkat çekici biçimde "Size mükemmel şekilde uyan daireler" olarak verilmiştir. Bir önceki örnekte görüldüğü gibi gerçekçi olmamakla birlikte illüstrasyonlar daha çok üç boyut hissini uyandırmaktadır (Görsel 18).

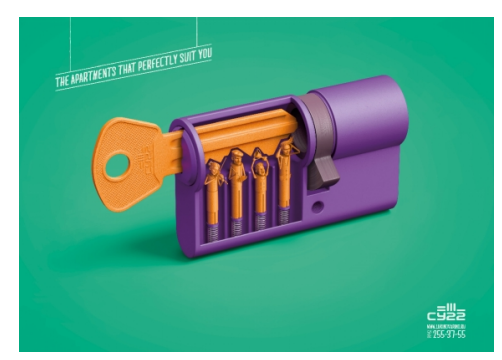

Görsel 18. SU22 afiş tasarımı, 2017

2019 Ocak ayında Meksika'da yayınlanan “Afirme ATM” reklamında iletilmek istenen "Açlık maaş beklemiyorEn yakın Afirme ATM'nizden doğrudan 6 bin Peso'luk Erken Maaşınızı alabilirsiniz" mesajı dikkat çekici ve etkileyici biçimde yine üç boyutlu gerçekçi olmayan bir illüstrasyon çalışması ile verilmiştir (Görsel 19).

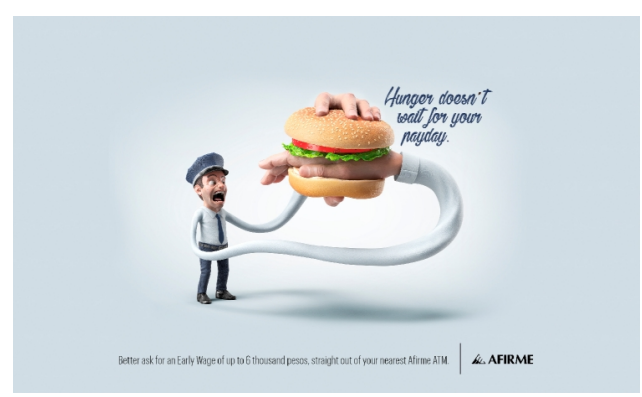

Görsel 19. Afirme ATM afiş tasarımı, 2019 
Farklı zamanlarda yayınlanmalarına rağmen üç farklı sektör reklamında da kullanılan illüstrasyon dili büyük benzerlikler taşımaktadır. Buradan hareketle bu tarz gerçekçi olmayan üç boyutlu illüstrasyon çalışmalarının ve grafik tasarım yaklaşımlarının geçtiğimiz yıllarda da kullanıldı̆̆ı, bundan sonraki yıl/yıllarda da kullanılmaya devam edeceği düşünülebilir.

\section{Dijital ve üç boyutlu tipografi tasarımları}

Gutenberg'in hareketli metal harfleri kullandığı matbaa makinesini buluşuyla birlikte tipografi teriminin de ortaya çıktığı söylenebilir. Tipografi yazı karakterlerinin, uygulama alanındaki renk, boşluk, illüstrasyon, fotoğraf gibi görsel ögelerin etkisini de göz önüne alarak tasarlanmasıdır. Temel olarak tipografi, harflerin ve kelimelerin nasıl düzenlendiğini, birbirleriyle nasıl ilişkili olduklarını ve bir kompozisyon içinde işgal ettikleri yeri içerir. Tipografi, yazı tiplerini seçtiğimizde ve tipografik düzenlemelerin okunuşu nasıl etkilemesi gerektiğine karar verdiğimiz zaman devreye girer (Harkins, 2010, s. 9). Amacı yazılı mesajların etkili, merak uyandırıcı ve anlaşılır biçimde karşı tarafa iletilmesidir. Dijital çağda yaşadığımız düşünülürse, tipografinin de teknolojiden etkilenmesi çok doğal karşılanmalıdır. Günümüzde üç boyutlu tipografiden hareketli tipografiye kadar birçok farklı uygulamaların grafik tasarım içerisinde yerini aldığını ve bu tasarım yaklaşımlarının sıklıkla kullanıldığını söyleyebiliriz.

Özellikle dijital tipografi uygulamalarında günümüze kadar tasarlanan örneklere baktığımız da geleneksel ve dekoratif yazıların fazla kullanılmadığı, çoğunlukla çentiksiz (serifsiz) ve modern yazı karakterlerinin tercih edildiğini görmekteyiz (Görsel 20, Görsel 21). Ancak 2019 yılına gelindiğinde bu durumun değiştiği, çentikli ve dekoratif yazı tiplerinin de dijital ortamda sıklıkla kullanılmaya başladığını söyleyebiliriz. Cesur yaklaşımlar olarak görülebilecek bu uygulama biçimi, süregelen modern yazı karakterlerinin kullanımı devam ederken farklılık yaratarak dikkat çekici bir unsur olarak karşımıza çıkmaktadır (Görsel 22, Görsel 23).

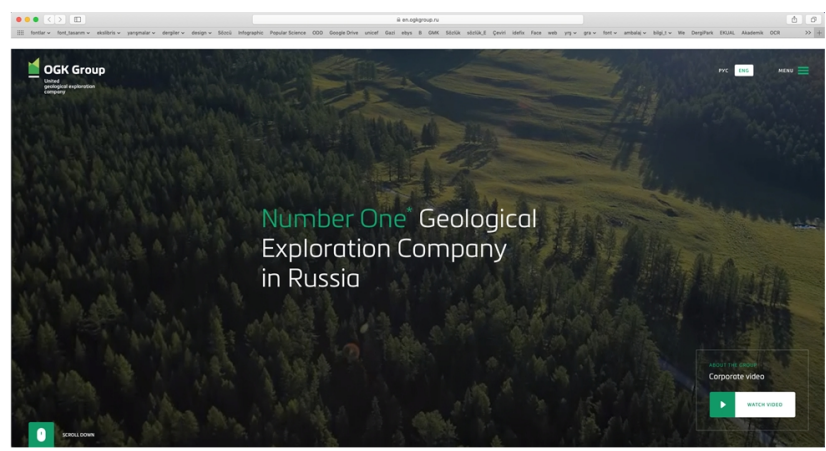

Görsel 20. UGK Group web sayfası tasarımı, 2019

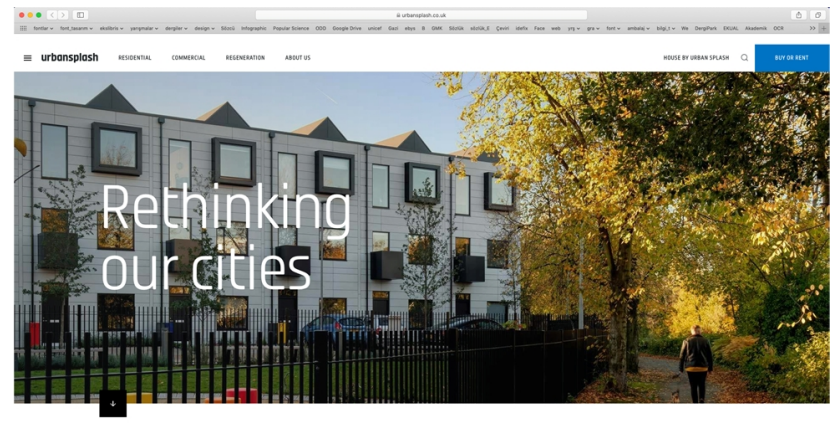

Görsel 21. Urban Splash web sayfası tasarımı, 2019

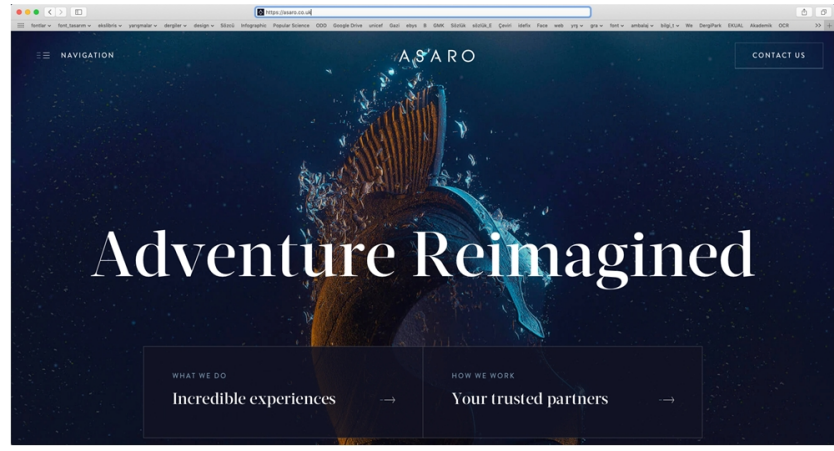

Görsel 22. Asaro web sayfası tasarımı, 2019 


\section{Customer \\ Experience \\ Monitor}

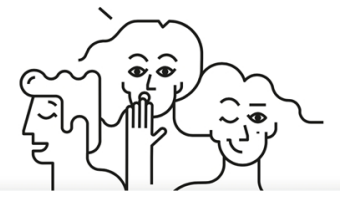

Görsel 23. Stimmt web sayfası tasarımı, 2019

Ayrıca yine 2018 yılında, modern yazı karakteriyle birlikte geleneksel yazı karakterlerinin bir arada kullanılması da dijital alanlarda karşılaşılan tasarım yaklaşımlarından biri haline gelmiştir. Görsel 24'de örneği görülen web sitesi tasarımında üst ve alt bölümde bulunan linklerde çentiksiz modern bir yazı karakteri kullanılırken, sayfa ortasında geleneksel ve çentikli bir yazı karakteri tercih edilmiştir. Görsel 25'de ise fotoğraf altlarında bulunan linklerde yine modern ve geleneksel çentikli yazı karakterleri birlikte kullanılmıştır. Bu dinamik kullanım görsel etkiyi arttırırken, süregelen tipografik yaklaşımlara bir alternatif olarak karşımıza çıkmaktadır. Özetle önümüzdeki yıllarda da bu tür tasarım yaklaşımlarının devam edeceği söylenebilir.

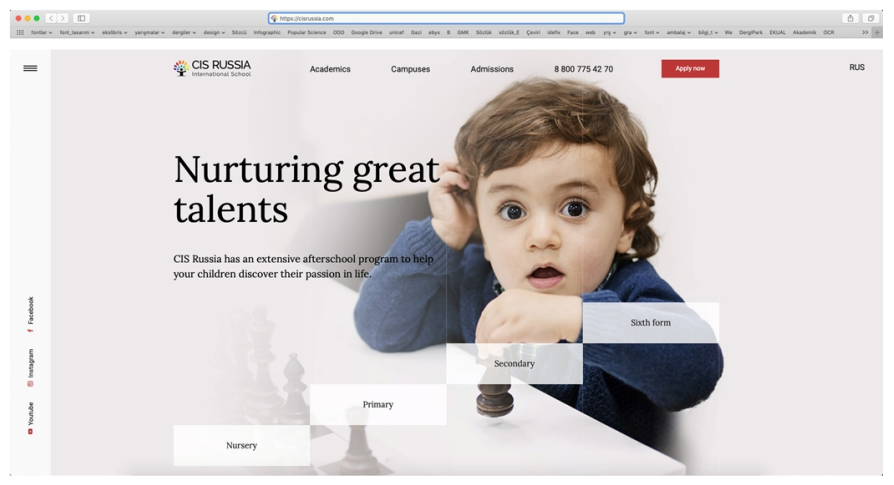

Görsel 24. Cis Russia web sayfası tasarımı, 2019

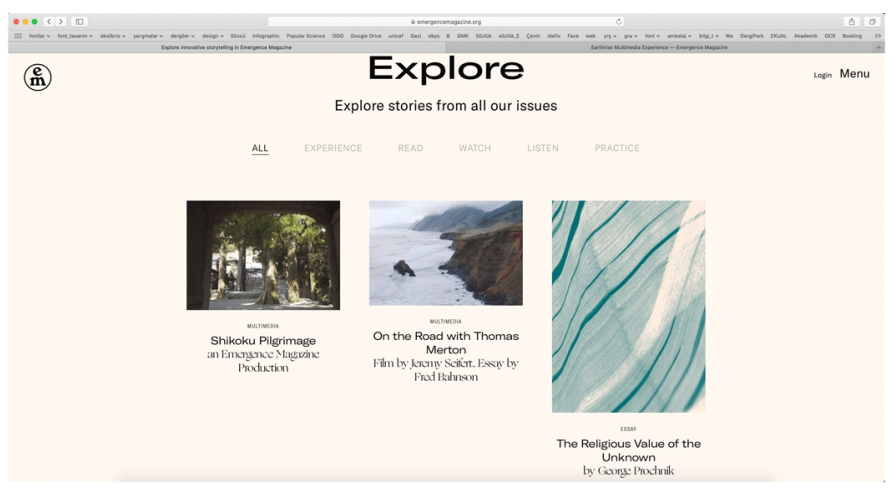

Görsel 25. Emergence Magazine web sayfası tasarımı, 2019

Tasarımda üç boyutlu tipografi uygulamaları giderek daha yaygın biçimde kullanılmaya başlanmıştır. Bunun en önemli nedeni, teknolojinin olumlu etkisi ile birlikte üç boyutlu tipografinin izleyiciyi hızlı bir biçimde istenilen şekilde yönlendirebilmesidir. Tasarımcılar yaratıcılık sınırlarını zorlayarak bu etkiyi arttırmayı amaçlamaktadırlar. İllüstratör Axel Bizon ve Lena Sarrault tarafından yapılan Legoland kitap kapağında tasarımcılar harfleri farklı açlardan üç boyutlu olarak hazırlamışlardır. Bu sayede tasarıma üç boyutlu bir hareket kazandırarak izleyicinin ilgisini çekmeyi amaçladıkları düşünülebilir (Görsel 26). Diğer örnekte ise bir dergi kapağı yer almaktadır. Burada da yine kullanılan tipografik yaklaşımda üç boyut hissi ön plana çıkartılarak etkin bir görsellik duygusu verilmeye çalışılmıştır (Görsel 27). Üç boyutlu tipografi uygulamalarının her alanda izleyici üzerindeki etkisi göz önüne alındığında önümüzdeki yıllarda bu tarz kullanımların çeşitlendirilmesini bekleyebiliriz (Görsel 28). 


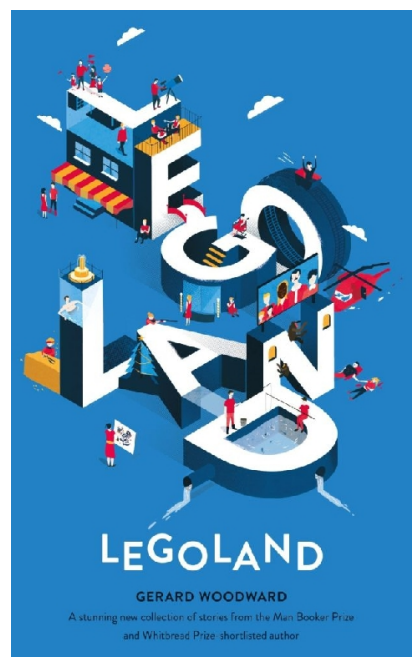

Görsel 26. Lego Land kitap kapağı tasarımı, 2016

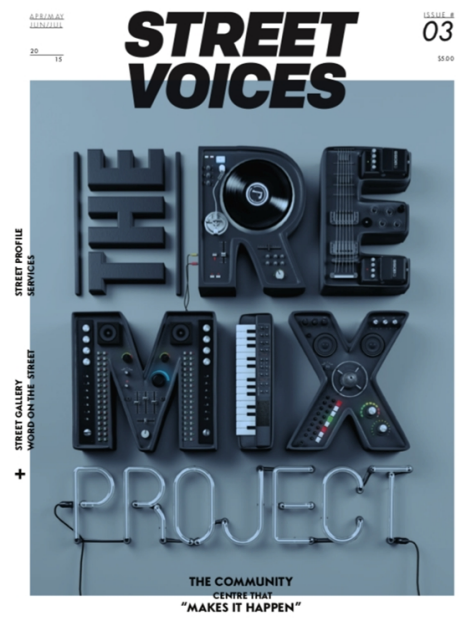

Görsel 27. Street Voices dergi kapağı tasarımı, 2015

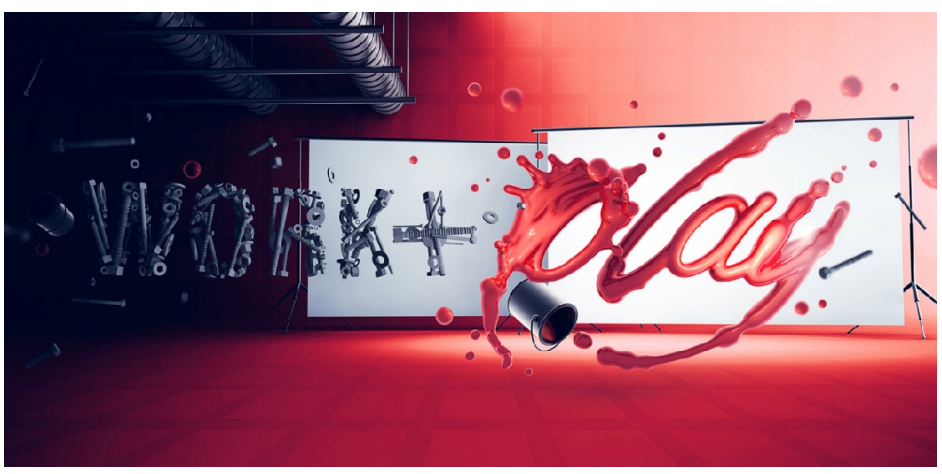

Görsel 28. Greyscalegorilla tasarım örneği, 2019

\section{6. İzometrik (Eşölçülü) tasarımlar}

İzometrik çizim, nesneleri ifade etmek için kullanılan yöntemlerinden biridir. Nesne gerçek değerlerinde üç temel boyutu esas alınarak yalnızca bir açıdan gösterilir. Ancak bir nesnenin, uzunluğunu, genişliğini ve derinliğini doğru değerlerinde gösterse bile gerçek bir perspektif görüntüsü vermez. Kısaca izometri; bir açıdan üç boyutlu nesnelerin görsel olarak iki boyutlu olarak temsil edilme halidir. İlk olarak mühendislik ve teknik çizimlerde kullanılmıştır. Ancak dijital oyun sektöründe izometrik tabanlı görsellerin uygulanmaya başlamasıyla tasarımcılar arasında da kullanımı yaygınlaşmışır. Özellikle web sitelerine boyut eklemek, düz nesnelerin sıkıcılığından 
kurtulmak ve ihtiyaç duyulan derinliği arttırmak amacı ile son yıllarda sıklıkla kullanılmaktadır (Görsel 29). Ayrıca izometrik tasarım yaklaşımının, kullanılan gölge ve perspektif uygulamaları ile izleyici üzerindeki etkisi arttırılarak dikkati yoğunlaştırmaya yardımcı olduğu da söylenebilir (Görsel 30, Görsel 31).

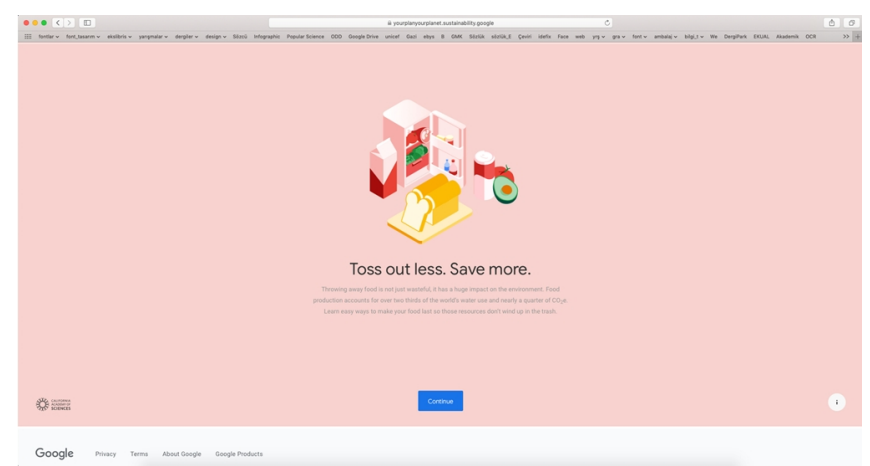

Görsel 29. Your Plan Your Planet web sayfası tasarımı, 2019

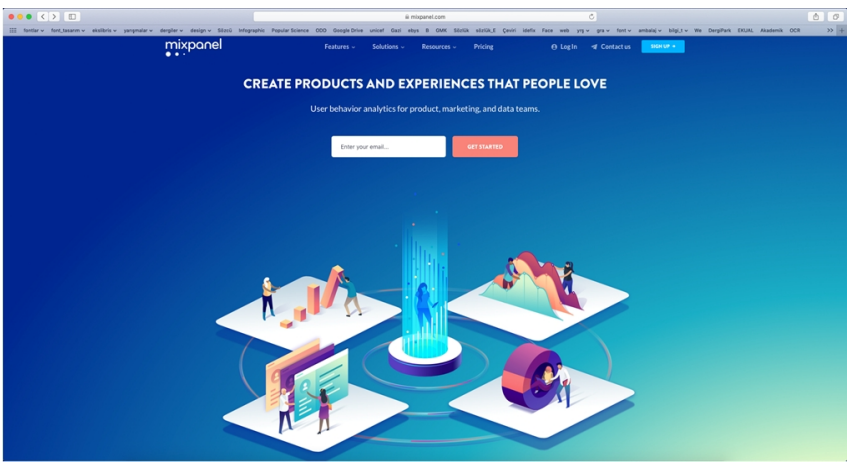

Görsel 30. Mixpanel web sayfası tasarımı, 2019

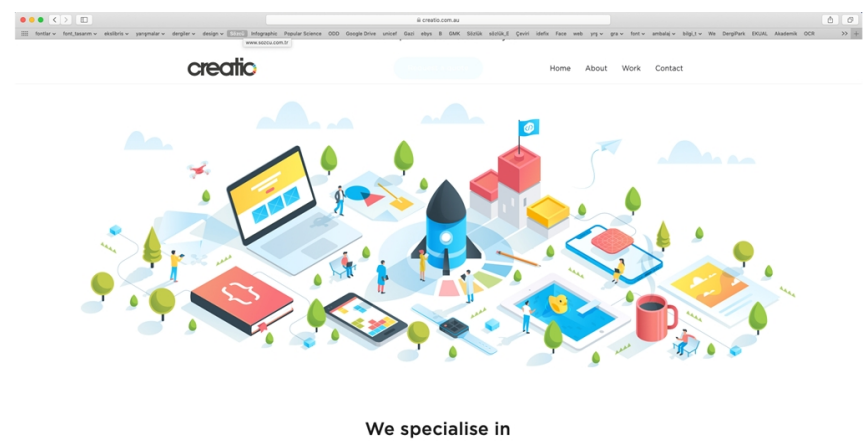

Görsel 31. Creatio web sayfası tasarımı, 2019

İnternet üzerinden dijital ortamlarda fotoğrafların görüntülenmesi oldukça uzun zaman almaktadır. Ancak izometrik nesnelerin fotoğrafın aksine matematiksel verilerden oluşması, görüntülerinin çok kısa sürede işlenmesini diğer bir deyişle internet üzerinden kullanılan ortamlarda çok hızlı biçimde görüntülenmesine olanak sağlamaktadır. Bu etkili özelliği ve kullanıcıya verdiği üç boyut hissi nedeniyle web sitelerinin yanı sıra telefon navigasyon (yolbul) uygulamalarında kullanımı özellikle tercih edilmektedir (Görsel 32). 


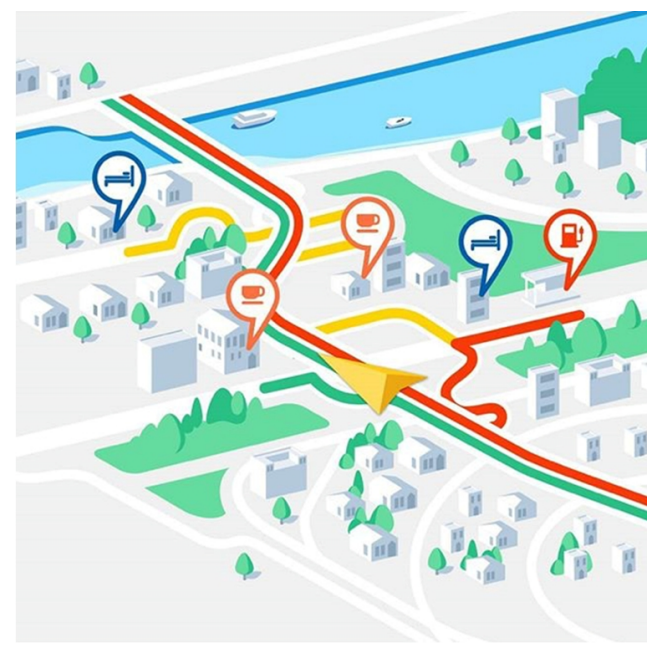

Görsel 32. Yandex Navigasyon, 2019

İzometrik tasarımın sayısal ortamda kullanımının kullanıcı üzerinde etkili olması, bu yaklaşımın diğer grafik tasarım alanlarında da ilgi görmesine neden olmuştur. Örneğin; Siemens firması 2015 yılında hazırladığı basılı medya reklamlarında izometrik tasarım dilini kullanmıştır. $\mathrm{Bu}$ tasarımda izometri sayesinde üç boyut hissi yaratılarak reklamın daha etkili olması sağlanmıştır (Görsel 33, Görsel 34). 2017 yılında Esso akaryakıt firmasının reklam afiş̧inde uzun bir yol üzerinde bulunan akaryakıt istasyonlarını illüstrasyon çalışması şeklinde yaptığı görülmektedir. İzometrik tasarım dilinin kullanıldığı bu afiş perspektif görüntüsü vermeden üç boyut hissini izleyici üzerinde yaratmaktadır. Renk seçimi sayesinde de oldukça etkili bir tasarım olduğu söylenebilir (Görsel 35). 2019 yılında biri Portekiz'de diğeri Türkiye'de yayınlanan iki ayrı reklam afişinde, grafik tasarım dilleri farklı olsa da izometrik tasarım uygulaması kontrast renklerin kullanımıyla birlikte etkili biçimde kullanılmıştır (Görsel 36, Görsel 37).

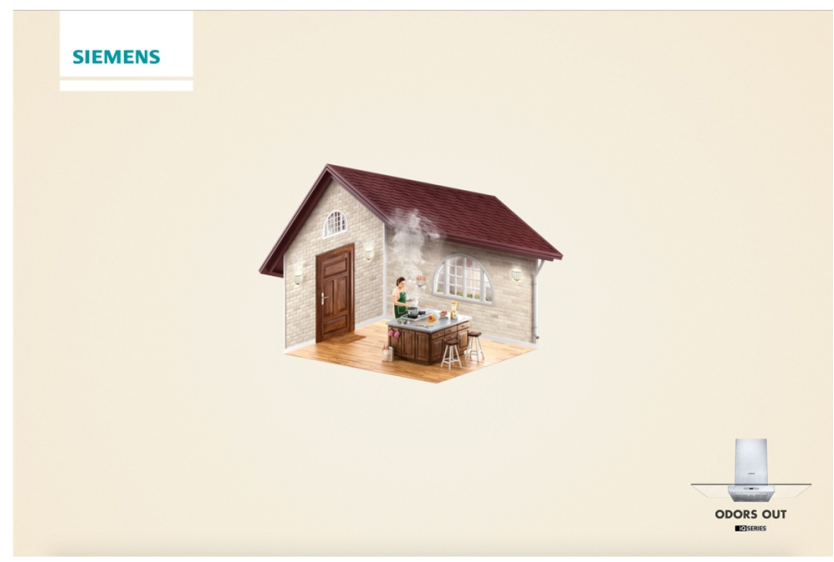

Görsel 33. Siemens afiş tasarımı, 2015

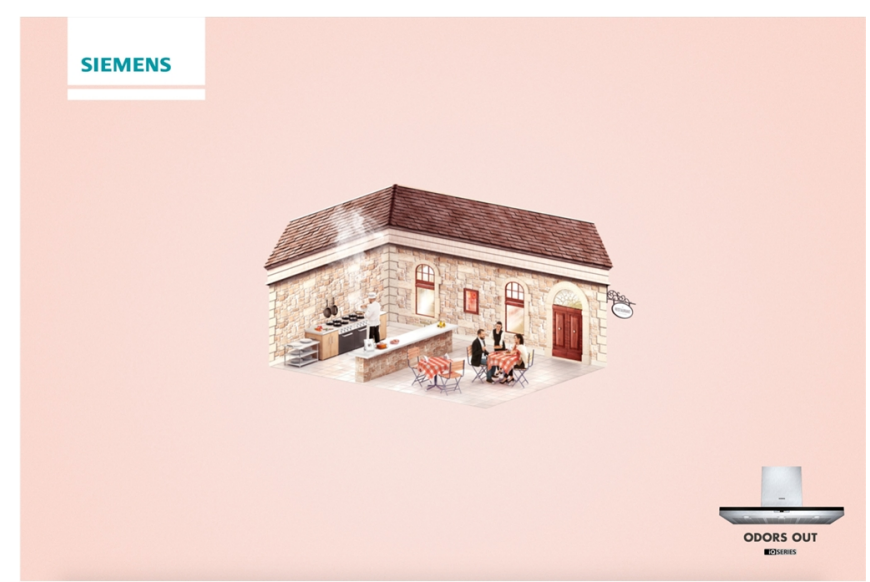

Görsel 34. Siemens afiş tasarımı, 2015 


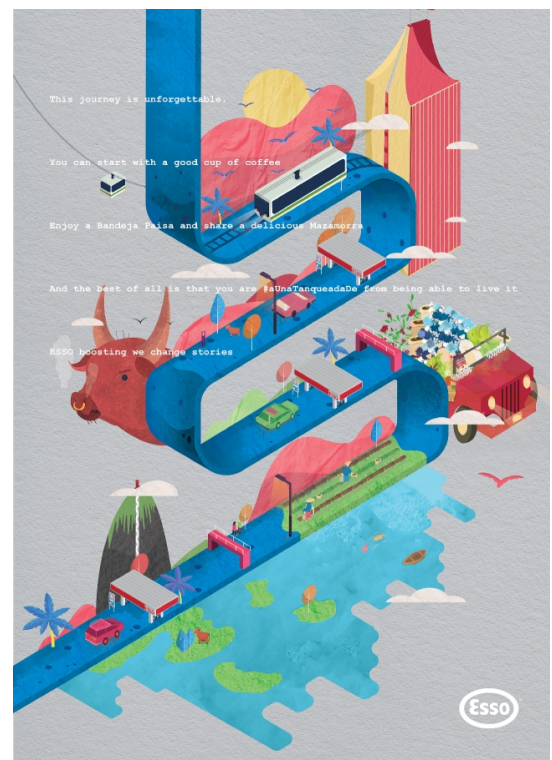

Görsel 35. Esso afiş tasarımı, 2017

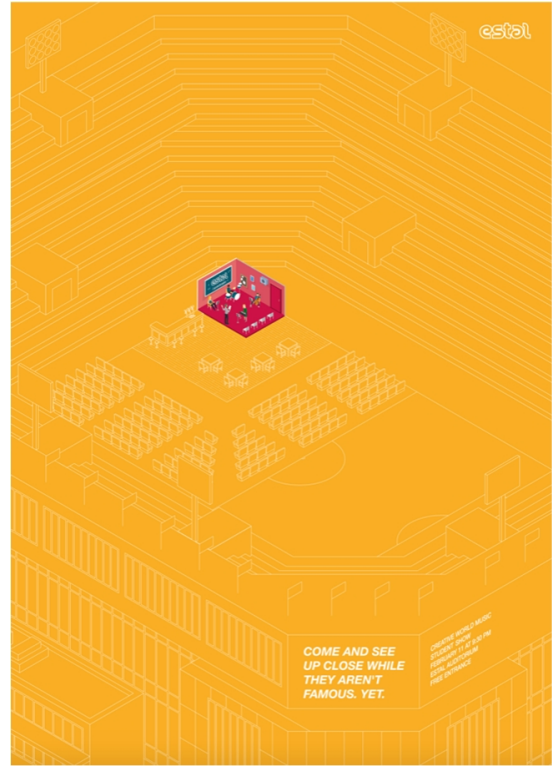

Görsel 36. Estal afiş tasarımı, 2019

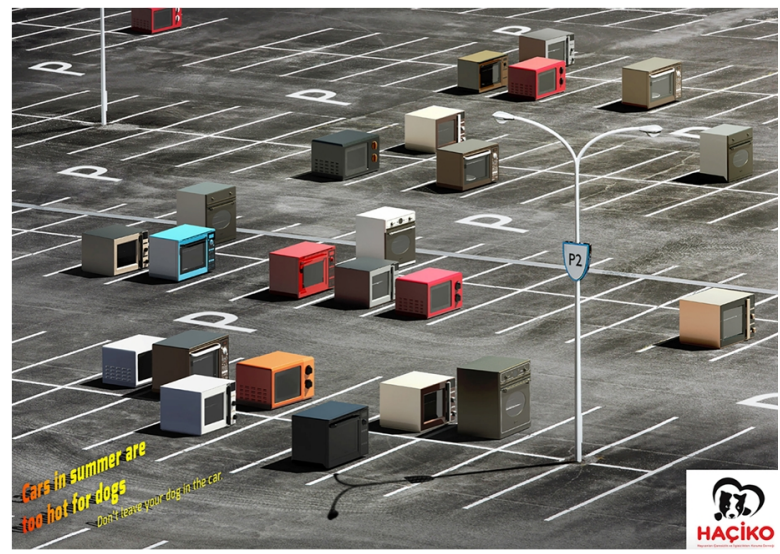

Görsel 37. Haçiko afiş tasarımı, 2019 


\section{Sanal gerçeklik (virtual reality)}

Günümüzde sıkça duymaya başladığımız "sanal gerçeklik ve arttırılmış gerçeklik" aslında uzun süredir bilim insanlarının araştırdığg ve üzerinde çalıştığı konulardır. Morton Heilig tarafından 1957 yılında tasarlanan Sensorama, ilk gerçeklik simülatörü olarak kabul edilmektedir. Kullanıcı bir sandalyeye oturtulur, önündeki tutacaklara dokunur, ekranda bir film gösterilir, bu sırada filme uyumlu olarak sandalye titreştirilir, içerideki fanlardan hava üflenir, hoparlörlerden sesler çıkarılırdı (Görsel 38). Buradan hareketle gerçekte Morton Heilig'in modern sanal gerçeklik teknolojisinin yaratıcısı olduğu söylenebilir (Martin, 2018, s. 6-7).

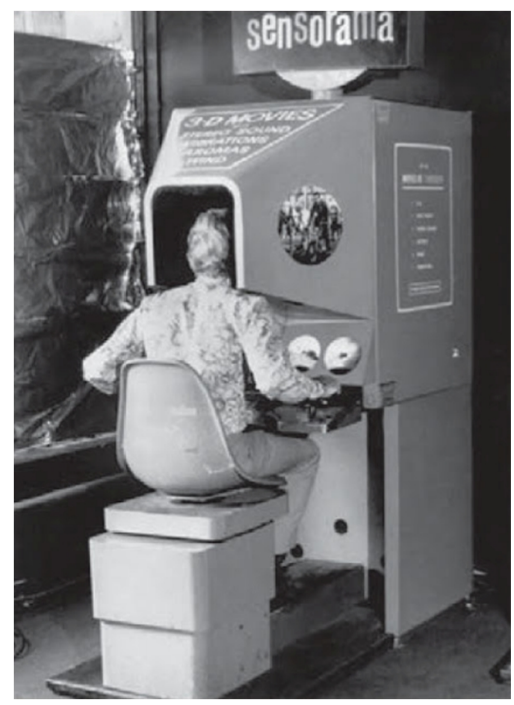

Görsel 38. Morton Heilig, Sensorama, 1957

Sanal gerçeklik teknolojileri ve uygulamaları, artık yalnızca deneysel araştırmalar olmaktan çıkıp çeşitli eklenti cihazlar (sanal gerçeklik gözlüğü, akıllı cep telefonlar, vb.) sayesinde son kullanıcı için ulaşılabilir duruma gelmiştir. Sanal gerçeklik, kullanıcıya o anda bulunduğundan farklı bir ortamda olma hissini üç boyutlu olarak deneyimleme firsatı sunmaktadır. Ancak kullanıcının bu deneyimi gerçekten yaşayabilmesi için arayüz tasarımlarının gerçekçi ve kusursuz olması gerekmektedir. Bu durum teknoloji üreticileri ile birlikte tasarımcıların üzerine de büyük bir yük getirmektedir. Kısaca, bir sanal gerçeklik uygulamasının başarılı olabilmesi, teknoloji kadar tasarımcının da yetenek, uygulama tekniği ve gerçekçi görsel hikâye anlatımına bağlıdır denebilir.

Adobe CC 2019 yılında “Adobe 180 ve 360/VR düzenleme: Daha sürükleyici bir hikâye anlatımı” sloganıyla sanal gerçeklik uygulama programını kullanıcılarına sunmuştur (Görsel 39). Programın açıklaması kısaca şöyledir; "İster film, ister video oyunu, ister eğitim videoları veya simülasyonlar oluşturun; 180 ve 360/VR videoları izleyicilerinizin kendilerini aksiyonun tam ortasında hissetmesini sağlar. İster Adobe Premiere Pro CC'de düzenleme yapın, ister Adobe After Effects CC'de hareketli grafikler ekleyin veya Adobe Photoshop CC'de çekimleri temizleyin; Adobe araçları sürükleyici videolar oluşturmak ve iyileştirmek için ihtiyacınız olan her şeyi sunar" (Adobe, 2019).

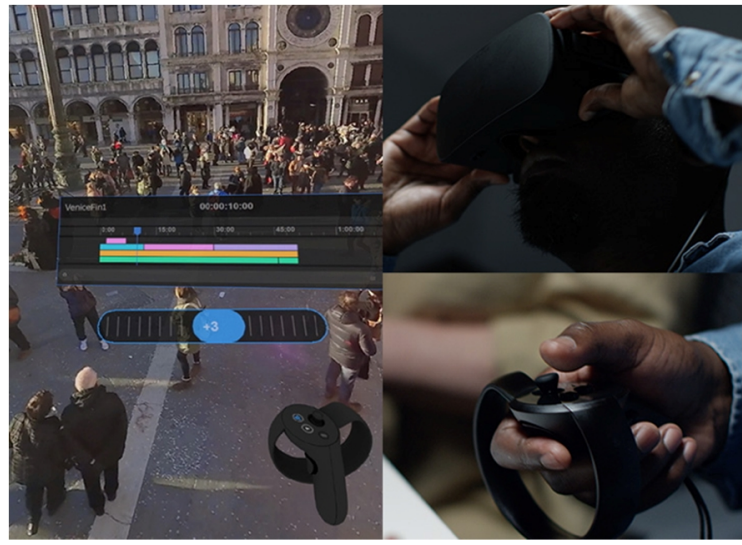

Görsel 39. Adobe 180 ve 360/VR düzenleme: daha sürükleyici bir hikâye anlatımı, 2019 
Sanal gerçeklik ayrıca son zamanlarda "artırılmış gerçeklik” adı verilen başka bir teknolojiyle de ortak bazı noktaları paylaşmaktadır. Sanal gerçeklik keşfedilecek sanal dünyalar yaratırken, artırılmış gerçeklik bilgisayar grafiklerini gerçek dünya ile birleştirir (Martin, 2018, s.10). Uygulama alanları çeşitlilik göstermekle birlikte; sanal oyun sektörü, akıllı telefon uygulamaları, tıp alanı, web siteleri, müze ve sergi gezi alanları olmak üzere geniş bir yelpazeyi kaplamaktadır. Özellikle önümüzdeki yıllarda sanal gerçeklik uygulamalarının arttırılmış gerçeklik ile birlikte tasarım alanında çok daha etkin biçimde adından söz ettireceği öngörülebilir.

\section{Sonuç}

Beş ayrı başlık altında ele alınan örnekler, gelişen teknolojinin tasarımcılar tarafından da etkin bir biçimde kullanıldığını göstermektedir. Sürekli değişimin kaçınılmaz olduğu tasarım alanı, renk tercihlerinin, illüstrasyon çeşitliliğinin, tipografi kullanımının, izometrik tasarım uygulamalarının ve sanal gerçekliğin izleyici üzerindeki etkisini bizlere göstermektedir. Teknolojinin sunduğu olanaklar, tasarım uygulama alanlarını hızla geliştirmekte ve buna paralel olarak çeşitlendirmektedir. Geçtiğimiz 10 yıllar içerisinde modern yaklaşımlar olarak benimsenen ve grafik tasarım uygulamalarında sıkça karşımıza çıkan birçok unsurun günümüzde kullanımının azaldığı, bir başka deyişle popülaritesini yitirdiği görülmektedir. Ancak bu tasarım unsurları günümüzün modern ve dijital çă̆ına da ilham kaynağı olduğu göz ardı edilmemelidir.

Teknolojinin bizlere sunduğu avantajlardan biri de artık tasarım alanında sınırların kaldırılıyor olmasıdır. Geleneksel ve modernin aynı potada eritildiği günümüzde bu sınırların kalkması birçok uygulama alanına özgürlük getirmektedir. Gerek grafik tasarım gerekse sanatsal açıdan olsun geleneksel ve dijitalin birleştirilmesi tasarımı ve sanatı bir adım daha ileriye taşıyacaktır. Bu durum çok daha etkili, dikkat çekici ve akılda kalıcı çizimlerin/tasarımların ortaya çıkarılmasına olanak sağlayacaktır.

Her gün yüzlerce iletişim aracıyla bombalandığımız gürültülü bir ortamda yaşadığımız düşünülürse, güncel/geleceğe dönük tasarım yaklaşımlarıyla farkındalık yaratmak, grafik tasarımcısı için büyük bir avantaj olarak görülebilir. Önümüzdeki yıllarda tasarım alanında daha birçok farklılık keşfedeceğiz. Bu keşifler bugün popüler olan tasarım yaklaşımlarını gelecekte belki de saf dışı bırakabilecektir. Ancak temel olarak tasarımcının hedefi ve sloganı hiçbir zaman değişmeyecektir; izleyiciyi ne şekilde olursa olsun etkilemek ve yönlendirmek.

\section{Kaynakça}

Adobe. (2019). Adobe 180 ve 360/VR düzenleme. Erişim adresi: https://www.adobe.com/tr/creativecloud/video/ virtual-reality.html\#x

Harkins, M. (2010). Basics Typography 02: using type. Switzerland: AVA Publishing.

Heller, S. (2009). Anathomy of design. Massachusetts: Rockport Publishers.

Male, A. (2017). Illustration atheoretical \& contextual perspective. London: Bloomsbury Visual Arts Publishing

Martin, B. S. (2018). Virtual reality. Chicago, Illinoid: Norwood House Press.

Öztuna, Y. K. (2007). Temel Tasarım Öğeleri: Renk. Grafik Tasarım Dergisi, 8, 99.

Pantone. (2018). Color of the year 2018 ultraviolet. Erişim adresi: https://www.pantone.com/colorintelligence/color-of-the-year/color-of-the-year-2018

\section{Görsel Kaynakçası}

Görsel 1. Hakkı Mısırlığlu, etkinlik afiş tasarımı. (2019), [Afiş]. Erişim adresi: http://gmk.org.tr/uploads/file/ edfa2bed8c302f9c55cbf1b85f25321b.jpg

Görsel 2. Game Over, sosyal kampanya afiş tasarımı. (2019), [Afiş]. Erişim adresi: https://d3nuqriibqh3vw. cloudfront.net/carnavalsocial_alcohol_new.jpg?BV7iy76XTVzHjmDK14 H1CawQTKncyWKR

Görsel 3. iPhone X arayüzü. (2019), [Ara Yüz]. Erişim adresi: https://www.apple.com/tr/iphone/

Görsel 4. Samsung Galaxy Note 9 web sayfası tasarımı. (2019), [Web Sayfas1]. Erişim adresi: https://www. samsung.com/tr/smartphones/galaxy-note9/

Görsel 5. Apple MacBook Air web sayfası tasarımı. (2019), [Web Sayfası]. Erişim adresi: https://www.apple. $\mathrm{com} / \mathrm{tr} / \mathrm{mac} /$

Görsel 6. Design Better web sayfası tasarım1. (2019), [Web Sayfası]. Erişim adresi: https://www.invisionapp.com/ design-better/design-maturitymodel/?hstc=146515115.009434f32c2366ace245b7fe356d253d.155177367 $2435.1551773672435 .1551773672435 .1 \& \_$hssc $=146515115.1 .1551773672435 \& \_\mathrm{hsfp}=10565101$

Görsel 7. The Engine Room London web sayfası tasarımı. (2019), [Web Sayfası]. Erişim adresi: https:// theengineroomlondon.com 
Görsel 8. Pantone Kataloğu web sayfası, yılın rengi: ultra violet 18-3838. (2019), [Renk Kataloğu]. Erişim adresi: https://www.pantone.com/color-intelligence/color-of-the-year/color-of-the-year-2018

Görsel 9. Mercedes A Serisi iç mekân gösterge paneli. (2019), [Araç İçi Ön Panel]. Erişim adresi: https://www.mercedes-benz.com.tr/passengercars/mercedes-benz-cars/models/aclass/hatchback/explore/highlights.module.html

Görsel 10. Wacom çizim tableti. (2019), [Tablet]. Erişim adresi: https://www.wacom.com.tr/

Görsel 11. Absolut içecek firması afiş tasarımı. (2004), [Afiş]. Erişim adresi: http://www.absolutads.com/gallery/reklama.php?id=1140

Görsel 12. Absolut içecek firması afiş tasarımı. (2008), [Afiş]. Erişim adresi: https://www.adsoftheworld.com/media/print/absolut_dissect_pear

Görsel 13. Absolut içecek firması afiş tasarımı. (2013), [Afiş]. Erişim adresi: https://www. adsoftheworld.com/media/print/absolut_catalyst

Görsel 14. Cappy Pulpy Mandalina afiş tasarımı. (2018), [Afiş]. Erişim adresi: https://www.behance.net/gallery/17673083/Cappy-Pulpy

Görsel 15. Cappy Atom afiş tasarımı. (2018), [Afiş]. Erişim adresi: https://www.behance.net/gallery/17411947/ Cappy-ATOM-TVC-Outdoor

Görsel 16. Cinema 4D Programıyla hazırlanan tasarım örneği. (2019), [Tasarım]. Erişim adresi: https://www. maxon.net/

Görsel 17. Audi Quattro afiş tasarımı. (2013), [Afiş]. Erişim adresi: https://www.adsoftheworld.com/media/print/ audi_sphere

Görsel 18. SU22 afiş tasarımı. (2017), [Afiş]. $\quad$ Erişim https://www.adsoftheworld.com/media/print/su22_look_1_0

Görsel 19. Afirme ATM afiş tasarımı. (2019), [Afiş]. Erişim adresi: https://www.adsoftheworld.com/media/print/afirme_hand_burger

Görsel 20. UGK Group web sayfası tasarımı. (2019), [Web Sayfası]. Erişim adresi: https://en.ogkgroup.ru

Görsel 21. Urban Splash web sayfası tasarımı. (2019), [Web Sayfası]. Erişim adresi: https://www.urbansplash.co.uk

Görsel 22. Asaro web sayfası tasarımı. (2019), [Web Sayfası]. Erişim adresi: https://asaro.co.uk

Görsel 23. Stimmt web sayfası tasarımı. (2019), [Web Sayfası]. Erişim adresi: https://stimmt.ch/customerexperience-2018/

Görsel 24. Cis Russia web sayfası tasarımı. (2019), [Web Sayfası]. Erişim adresi: https://cisrussia.com

Görsel 25. Emergence Magazine web sayfası tasarımı. (2019), [Web Sayfası]. Erişim adresi: https://emergencemagazine.org/explore/

Görsel 26. Lego Land kitap kapağı tasarımı. (2016), [Kitap Kapağı]. Erişim adresi: http://www.casualoptimist.com/blog/2016/02/08/book-covers-of-note-february-2016/

Görsel 27. Street Voices dergi kapağı tasarımı. (2015), [Dergi Kapağı]. Erişim adresi: https://www.streetvoices.ca/magazine

Görsel 28. Greyscalegorilla tasarım örneği. (2019), [Tasarım]. Erişim adresi: https://greyscalegorilla.com/

Görsel 29. Your Plan Your Planet web sayfası tasarımı. (2019), [Web Sayfası]. Erişim adresi: https://yourplanyourplanet.sustainability.google/food-pillar/amount

Görsel 30. Mixpanel web sayfası tasarımı. (2019), [Web Sayfası]. Erişim adresi: https://mixpanel.com

Görsel 31. Creatio web sayfası tasarımı. (2019), [Web Sayfası]. Erişim adresi: https://www.creatio.com.au

Görsel 32. Yandex Navigasyon. (2019), [Telefon Uygulaması]. Erişim adresi: https://yandexnavigasyon.com.tr/

Görsel 33. Siemens afiş tasarımı. (2015), [Afiş]. Erişim adresi: https://d3nuqriibqh3vw.cloudfront.net/siemens_ cooker_hood_house_aotw.jpg 
Görsel 34. Siemens afiş tasarımı. (2015), [Afiş]. Erişim adresi: https://d3nuqriibqh3vw.cloudfront.net/siemens cooker_hood_restaurant_aotw.jpg

Görsel 35. Esso afiş tasarımı. (2017), [Afiş]. Erişim adresi: https://d3nuqriibqh3vw.cloudfront.net/paisa_0.jpg

Görsel 36. Estal afiş tasarımı. (2019), [Afiş]. Erişim adresi: https://d3nuqriibqh3vw.cloudfront.net/poster estal.jpg?1nXqTvE3fbM2S6mY0Nuo_tIHI75PqJZg

Görsel 37. Haçiko afiş tasarımı. (2019), [Afiş]. Erişim adresi: https://d3nuqriibqh3vw.cloudfront.net/haciko print.jpg?t22KGg5js2O.7lU_.pRGffrYkLitROD8

Görsel 38. Morton Heilig, Sensorama. (1957), [Fotoğraf]. Erişim adresi: https://books.google.com.tr/ books?id=bNwyDwAAQBAJ\&printsec=frontcover\&dq=Virtual+Reality\&hl=tr\&sa=X\&ved=0ahUKEwi 474Lzh97gAhVO_6QKHZS1COkQ6AEIMDAB\#v=onepage\&q=heil\&f=false

Görsel 39. Adobe 180 ve 360/VR düzenleme: daha sürükleyici bir hikaye anlatımı. (2019), [Sanal Gerçeklik Uygulama Programı]. Erişim adresi: https://www.adobe.com/tr/creativecloud/video/virtual-reality.html\#x 